The patient of Faux et al. (1973) was a 3-year-old boy with recurrent respiratory infections and otitis media from the age of 6 months. There is no mention of dyspnoea or of radiological appearances. The patient described by Moroz et al. (1971) was a woman aged 30 with a history of repeated tonsillitis since childhood. No description is given of chest $x$-rav pioture or mediastinal glands. In this case the abnormal IgA was also detected in two svmptomless relatives, and culture of the patient's tonsillar lvmphocytes showed that they were able to synthesize light chains as well as alpha-heavy chains, suggesting a familial defect of assembly. This patient's urine contained both alpha-chains and Bence Jones proteins. In the Dutch girl only a trace of alpha-chains was detected and in the boy nothing was found on seventy-fold urinary concentrations.

In heavy-chain disease generally the concentration and molecular weight of the abnormal proteins vary considerably, hence the irregular urinary excretion. Bence Jones proteinuria is usually minimal and in some cases no light chains seem to be synthesized (Seligmann et al., 1968). In both the intestinal and the pulmonary forms of alpha-chain disease the abnormal immunoglobulin is devoid of light chains and the heavy chains show varying degrees of deletion in the aminoacid sequence, concerning mainly the $\mathrm{Fd}$ portion (Frangione et al., 1971).

None of the pulmonary cases including our own showed any evidence of lymphoma. Stoop et al.'s girl developed a pharyangeal paragranuloma in which, however, no IgA-secreting cells could be shown. The disease seems to be fairly benign since three patients are alive and our patient died at 78 without any evidence of malignancy at necropsy. He had a heavy proteinuria, but unfontunately the urine was not studied since the diagnosis was not suspected during life. In the serum the IgA consisted entirely of abnormal alpha-chains, suggesting that the synthesis of normal IgA molecules was inhibited. This alpha-chain differs from those in previous cases in that it seems to have an antibody activity detected by immunofluorescence and directed against a constituent of rat mitochondria. It is usually considered that both heavy-chain and light-chain $\mathrm{N}$-terminals are needed for antibody activity, but there is another precedent in a Bence Jones protein reported by Oscerman et al. (1964) which apparently gave a cytoplasmic fluorescence on several tissues. Possibly this antibody activity represents a coss reaction with a bacterial or viral antigen. Further studies on the nature of the antigen are in progress. So far it is known that the patient's serum showed no high titres of antibodies to rubella, measles, and herpes tvpe 1 viruses, and absorption with cardiolipin (Venereal Disease Research Laboratory antigen), streptolysin $\mathrm{O}$, and staphylolysin failed to inhibit the mitochondrial fluorescence seen on rat tissues.

W/e thank Dr. G. Bull and Miss Iris Cotgrove for their helpful advice, Mr. G. Swana for his expert technical help, and Miss Hilary Fischler for preparation of the manuscript. A. F-C. is in receipt of a Wellcome Trust Felllowship. Work in the Department of Immunology is supported by the Medical Research Council and the World Health Organization.

\section{References}

Doniach, D. (1972). Progress in Clinical Immunology, 1, 45.

Faux, J. A., Crain, J. D., Rosen, F. S., and Merler, E. (1973). Clinical Immunology and Immunopathology, 1,282

Frangione, B., et al. (1971). Annals of New York Academy of Sciences, 190, 71 Frangione, B., and Franklin, E. C. (1973). Seminars in Haematology, 10, 53. (1971). Fournal of Clinical Investigation, 50,2726

Osserman, E. F., Takatsuki, K., and Talal, N. (1964). Seminars in Haematology, 1, 3 .

Scheidegger, J. J. (1955). International Archives of Allergy and Applied Immunology, $7,103$.

Seligmann, M., Danon, F., Hurez, D., Mihaesco, E. and Preud'homme, J. L. Science, 1968, 162, 1397

Seligmann, M. (1972). European fournal of Clinical and Biological Research, 17,349

Stoop, J. W., Ballieux, R. E., Hijmans, W., and Zegers, B. J. M. (1971) Clinical and Experimental Immunology, 9, 625.

Wright, D. J., and Doniach, D. (1971). Proceedings of the Royal Society of Medicine, 64, 519 .

\title{
Sensitivity to Rifampicin: Incidence, Mechanism, and Prevention
}

\author{
JEAN-CLAUDE PUJET, JEAN-CLAUDE HOMBERG, GUY DECROIX
}

British Medical fournal, 1974, 2, 415-418

\section{Summary}

Five out of 200 patients taking rifampicin $900 \mathrm{mg}$ twice weekly and three out of 91 patients taking rifampicin who attended an immunology clinic developed intolerance to the drug. Antibodies to rifampicin, which were found in most cases, decreased steadily after the end of treatment but were detectable for up to 16 months. The dose of rifampicin and the blood levels are predominating factors in the occurrence of reactions. Thus the dose should be reduced in patients in whom rifampicin blood levels rise abnormally. When it is

\section{Centre Medico-Chirurgical de Cambo}

JEAN-CLAUDE PUJET, M.D.

Centre Departemental de Transfusion Sanguine de Paris

JEAN-CLAUDE HOMBERG, M.D., Head of the Immunopathology Laboratory

H6 pital Saint-Antoine, 75012 Paris

GUY DECROIX, M.D., Professor of Medicine and Head of Department of Diseases of the Chest important to continue rifampicin treatment despite intolerance antibody titres within 24 hours after administration of the drug must be measured to find when they are lowest, which determines the "unreactive period," and when a further dose may be safely given.

\section{Introduction}

A combination of rifampicin $900 \mathrm{mg}$ and isoniazid $750 \mathrm{mg}$ given twice weekly seems as effective in the treatment of tuberculosis as rifampicin $600 \mathrm{mg}$ and isoniazid $450 \mathrm{mg}$ given daily (Decroix et al., 1971). A disadvantage of the twiceweekly regimen, however, is that side effects occur, which seem to be related to the intermittent use of rifampicin (Blajchman et al., 1970; Poole et al., 1971). To investigate the reasons for these adverse reactions in intermittent therapy we studied the cases of a group of patients followed up after their discharge from hospital and of another group who had been referred for immunological investigation to the Centre Départemental de Transfusion Sanguine of Paris (C.D.T.S.). This paper reponts our findings. Though these confirmed those of others, there were certain differences which we think 
have an important bearing on the prevention of side effects to rifampicin.

\section{Patients and Methods}

The cases of two groups of patients, a total of 291, were studied. The first group comprised 200 hospital patients. Of these 50 had received rifampicin $900 \mathrm{mg}$ and isoniazid 750 mg twice weekly from the start of their treatment in 1969, and the remaining 150 had begun this intermittent regimen after an initial three-month period of daily rifampicin. The patients came from four different hospitals and all had completed their treatment when the study was made. The results of treatment have been reported (Decroix et al., 1971). The second group comprised 91 patients whose serum had been sent to the C.D.T.S. either for systematic immunological studies or because of side effects.

Serum rifampicin levels had been determined routinely in 30 of the 200 hospital patients after six months' treatment. Serum rifampicin levels had also been determined in another two patients who had presented with adverse reactions. Determinations were made by observing the inhibitory effect of serum on a culture of Sarcina lutea I.P. 5,345 in a gelose nutrient three, six, and eight hours after a single $900-\mathrm{mg}$ dose of rifampicin.

An antiglobulin test in the presence of the drug and a lymphocyte transformation test had been carried out in the immunological study of an adequate number of cases.

\section{ANTIGLOBULIN TEST}

The same technique was used for all sera in the antiglobulin test and three reactions were observed in each serum. For the first, one drop of patient's serum (either pure or diluted in saline) was mixed with one drop of rifampicin $60 \mathrm{mg} / 100$ $\mathrm{ml}$ saline, one drop of compatible normal human red cells in $5 \%$ suspension in saline, and one drop of fresh compatible serum. For the second (serum control) the patient's serum, compatible normal human red cells, and fresh compatible human serum were mixed and saline was substituted for rifampicin. For the third (rifampicin control) the rifampicin solution, compatible normal human red cells, and fresh compatible human serum were mixed. The serum of a patient receiving no rifampicin treatment was substituted for the patient's serum. The three mixtures were incubated at $37^{\circ} \mathrm{C}$ for two hours, and, after washing, the antiglobulin test was then carried out. The antiglobulin used (Institut Pasteur, Paris, Lot 8,661) had been chosen for its high anticomplementary activity.

The rifampicin solution used in the tests was taken from a stock solution prepared by dissolving one $300-\mathrm{mg}$ rifampicin capsule in $500 \mathrm{ml}$ of saline. The drug dissolved completely within 48 hours. (This solution can be kept for six months without appreciable loss of activity if stored at $4^{\circ} \mathrm{C}$ and sheltered from light.) For a positive reaction the strength of the rifampicin solution had to be at least $1-10 \mathrm{mg} / 100 \mathrm{ml}$ saline, and the stronger the solution the more clear-cut was the reaction.

If enzyme-treated red blood cells are used in the test the reaction is stronger, with a titre two dilutions higher, but about $2 \%$ of sera agglutinate enzyme-treated red cells at $37^{\circ} \mathrm{C}$ and the antiglobulin must be checked against such red cells. We therefore preferred to use untreated normal red blood cells. With normal red cells incubation at $37^{\circ} \mathrm{C}$ must be for two hours for an optimum reaction, but with enzymetreated cells the incubation period is one hour. The reaction is usually negative with the anti-IgG, anti-IgA, and anti-IgM antiglobulins (Sors et al., 1972). Only anticomplement antiglobulins are effective in all cases.
LYMPHOCYTE TRANSFORMATION TEST

Lymphocytes for the lymphocyte transformation test were cultured with the following concentrations of rifampicin: 3, $7,15,37,75,150$, and $300 \mathrm{mg} / \mathrm{ml}$. Readings were made on the fourth day. Results were judged to be negative when fewer than $1 \%$ of cells were transformed and positive when more than $4 \%$ were transformed. When the results were equivocal the culture was repeated.

\section{Results}

Eight cases of immunological intolerance had been found, of which five were among the group of 200 hospital patients who had been on intermittent rifampicin treatment-an incidence of $2.5 \%$. Of the three cases of immunological intolerance among the group of 91 patients referred to the C.D.T.S. one had been on intermittent treatment and two had been on continuous rifampicin therapy (600 mg daily). Side effects had recurred in these two patients when treatment was restarted.

In every case the adverse reactions had occurred after several weeks of rifampicin therapy-mostly after a period of between three and 15 months. In one patient (case 1, table I) rifampicin had been given intermittently $(900 \mathrm{mg}$ twice weekly) from the start. Side effects occurred at the end of the third month. In five patients (cases 2-6) $600 \mathrm{mg}$ rifampicin daily for the first three months had been followed by an intermittent regimen of $900 \mathrm{mg}$ twice weekly. Side effects occurred after six to 18 months. One of these patients (case 3) had again had adverse reactions eight weeks after rifampicin treatment was resumed with a smalled twiceweekly dose of $300 \mathrm{mg}$. The two patients (cases 7 and 8) who had developed adverse reactions while on continuous therapy had again had side effects when a $600-\mathrm{mg}$ dose of rifampicin was given 30 and 75 days respectively after cessation of treatment.

The symptoms of adverse reaction in each case had showed from one to four hours after a dose of rifampicin. Recovery had occurred spontaneously within 10 hours. The symptoms were mainly those of a chill with fever and associated myalgia. Renal failure developed in three cases, haemolysis in one, and purpura in another (table I). Adverse reactions when they recurred were always of the same type. Four patients respectively had the following number of reaotions: five (case 2), seven (case 3), four (case 4), and fifteen (case 1). The remaining four patients had one reaction each.

TABLE I-Clinical Manifestations of Intolerance to Rifampicin presented by Eight Patients. Cases 1-5 belong to the Group of 200 followed-up Patients

\begin{tabular}{|c|c|c|c|c|c|c|}
\hline $\begin{array}{l}\text { Case } \\
\text { No. }\end{array}$ & $\begin{array}{l}\text { Chills, } \\
\text { Pyrexia }\end{array}$ & Myalgia & $\begin{array}{c}\text { Nausea, } \\
\text { Diarrhoea }\end{array}$ & Haemolysis & Purpura & $\begin{array}{c}\text { Anuria } \\
\text { (No. of } \\
\text { Days } \\
\text { Duration) }\end{array}$ \\
\hline $\begin{array}{l}1 * \\
2^{*} \\
3^{*} \\
4^{*} \\
5^{*} \\
6^{*} \\
7^{*} \\
8^{\dagger}\end{array}$ & $\begin{array}{l}++ \\
++ \\
++ \\
++ \\
++ \\
++ \\
++ \\
+\end{array}$ & $\begin{array}{l}++ \\
++ \\
++ \\
++ \\
++ \\
++ \\
++ \\
+\end{array}$ & $\begin{array}{l}+ \\
+ \\
++ \\
++\end{array}$ & + & ++ & $\begin{array}{l}+(2) \\
++(8) \\
++(17)\end{array}$ \\
\hline
\end{tabular}

$+=$ Mild symptoms. $++=$ Severe symptoms.

$\dagger$ Patients on a daily regimen of rifampicin, which was resumed after an interval.

Comparison of the serum rifampicin levels in 29 patients who did not have adverse reactions with the levels in three patients who did have reactions showed that the levels in the reactors were five times higher after three hours and five to 10 times higher after six or eight hours (table II).

Out of 156 antiglobulin tests that had been done on 123 patients on rifampicin treatment the results were positive in seven of the eight patients who had had an adverse reaction. 
Among the remaining 116 patients in whom the result of the test was negative was the eighth patient (case 3 ) who had had an adverse reaction. In this case the test had been done six months after the reaction had occurred. Ninety-five of the 123 patients tested had no clinical disorder; 16 had developed hepatic disease with jaundice and raised serum transaminase levels; and four had had various reactions unrelated to rifampicin.

TABLE II-Rifampicin Levels $(\mu \mathrm{g} / \mathrm{ml})$ after a Single Dose of Rifampicin $900 \mathrm{mg}$ in 29 Patients without Adverse Reactions and in Three Patients with Reaction

\begin{tabular}{|c|c|c|c|c|}
\hline & \multirow{2}{*}{$\begin{array}{c}\text { Duration of } \\
\text { Treatment } \\
\text { (Months) }\end{array}$} & \multicolumn{3}{|c|}{ Hours after Administration } \\
\hline & & 3 & 6 & 8 \\
\hline Reactors $\left\{\begin{array}{l}\text { case } 2 \\
\text { case } 3 \\
\text { case } 5\end{array}\right.$ & $\begin{array}{r}9 \\
10 \\
6\end{array}$ & $\begin{array}{l}40 \\
42 \\
12\end{array}$ & $\begin{array}{l}40 \\
21\end{array}$ & 10 \\
\hline$\underset{\text { non-reactors }}{\text { Mean values in } 29}$ & 6 & 8.5 & $4 \cdot 6$ & 1.8 \\
\hline
\end{tabular}

Rifampicin antibody titres before and after adverse reactions in the eight patients are shown in table III. Some still had small amounts of antibody in their serum 16 months after the reaction. After a single test dose of rifampicin 900 $\mathrm{mg}$ in one patient (case 2) antibody titres had decreased rapidly up to 12 hours and had then reappeared after about 24 hours (table IV).

TABLE IV-Rifampicin Antibody Titres after a Single 900-mg Dose of Rifampicin in Case 2

\begin{tabular}{|c|c|c|c|c|c|c|}
\hline \multirow{2}{*}{$\begin{array}{l}\text { Hours After } \\
\text { Administration }\end{array}$} & \multicolumn{6}{|c|}{ Dilution of Serum } \\
\hline & $\frac{1}{1}$ & $\frac{1}{2}$ & $\frac{1}{4}$ & $\frac{1}{8}$ & $\frac{1}{16}$ & $\frac{1}{32}$ \\
\hline $\begin{array}{r}1 \\
3 \\
6 \\
12 \\
24\end{array}$ & $\begin{array}{c}++ \\
++ \\
+ \\
+ \\
++\end{array}$ & $\begin{array}{r}++ \\
+ \\
+\end{array}$ & $\begin{array}{r}++ \\
+ \\
+\end{array}$ & ++ & + & \\
\hline
\end{tabular}

TABLE v-Incidence of Side Effects according to Dose of Rifampicin

\begin{tabular}{|c|c|c|c|c|}
\hline $\begin{array}{c}\text { Rifampicin } \\
\text { Dosage (1-3 } \\
\text { Times } \\
\text { Weekly) }\end{array}$ & Series & $\begin{array}{l}\text { No. of } \\
\text { Patients }\end{array}$ & $\begin{array}{l}\text { No. of } \\
\text { Side } \\
\text { Effects }\end{array}$ & $\begin{array}{l}\text { Incidence } \\
\text { of Side } \\
\text { Effects }\end{array}$ \\
\hline $\begin{array}{l}10 \mathrm{mg} / \mathrm{kg} \\
(400 \text { or } 600 \mathrm{mg})\end{array}$ & $\left\{\begin{array}{l}\text { Gomi (1971) } \\
\text { Silveira (1971) }\end{array}\right.$ & $\begin{array}{r}65 \\
18 \\
200\end{array}$ & $\left.\begin{array}{l}0 \\
0 \\
5\end{array}\right\}$ & $0 / 83$ \\
\hline $\begin{array}{l}15 \mathrm{mg} / \mathrm{kg} \\
(900 \mathrm{mg})\end{array}$ & $\left\{\begin{array}{l}\text { Larbaoui et al. }(1971) \\
\text { Mallorquin et al. (1971) } \\
\text { Mannes et al. (1973) }\end{array}\right.$ & $\begin{array}{r}120 \\
16 \\
28 \\
150\end{array}$ & $\begin{array}{r}1 \\
0 \\
5 \\
33\end{array}$ & $\begin{array}{l}11 / 364 \\
(3 \%)\end{array}$ \\
\hline $\begin{array}{l}20 \mathrm{mg} / \mathrm{kg} \\
(1200 \mathrm{mg})\end{array}$ & $\left\{\begin{array}{l}\text { Poole et al. (1971) } \\
\text { Sepulveda et al. (1971) } \\
\text { Zierski (1971) }\end{array}\right.$ & $\begin{array}{r}49 \\
46 \\
100\end{array}$ & $\begin{array}{r}11 \\
7 \\
14\end{array}$ & $\begin{array}{l}65 / 345 \\
(18 \cdot 8 \%)\end{array}$ \\
\hline $\begin{array}{l}30 \mathrm{mg} / \mathrm{kg} \\
(1800 \mathrm{mg})\end{array}$ & $\left\{\begin{array}{l}\text { Aquinas et al. (1972) } \\
\text { Doyle et al. (1971) } \\
\text { Eule (1971) } \\
\text { Hermann (1972) } \\
\text { Sepulveda et al. (1971) } \\
\text { Verbist et al. }(1972)\end{array}\right.$ & $\begin{array}{r}52 \\
74 \\
39 \\
50 \\
94 \\
100\end{array}$ & $\begin{array}{r}27 \\
1 \\
12 \\
20 \\
21 \\
0\end{array}$ & $\begin{array}{l}81 / 409 \\
(19.8 \%)\end{array}$ \\
\hline
\end{tabular}

Lymphocyte transformation tests had been performed in 45 patients. The results were negative in five patients who had had adverse reactions (cases $1,2,4,7$, and 8) and in 39 patients who had developed hepatic disorders. Only one result was equivocal.

\section{Discussion}

The clinical manifestations of sensitivity to rifampicin are of two kinds. The first is of digestive disorders, particularly of the liver. They occur at the beginning of treatment irrespective of the regimen (Decroix and Pujet, 1973). The results of immunological investigations in these cases have been negative. The second kind of manifestation is systemic in the form of chill, fever, muscle pain, and diarrhoea and vomiting. These are sometimes associated with renal disorder (Kleinkneich et al., 1972; Decroix et al., 1973) or cytopenia (Sors et al., 1972). These reactions occur after a fairly long period of treatment and only when rifampicin has been given in an intermittent regimen.

Matters of interest in connexion with rifampicin sensitivity which must be discussed are the effeot of dosage and the interval between doses, the immunological tests for the presence of antibodies, and the mechanism of the reactions.

\section{EFFECT OF DOSAGE}

Reactions to rifampicin seem to be related to the concentration of the drug in the blood. This may be affected by dosage or by the rate of metabolism. The incidence of side effects in relation to dosage in several series of cases are shown in table V. That drugs must first be bound to plasma proteins to become antigenic (Landsteiner et al., 1945) is generally accepted. Probably high serum concentrations of rifampicin, which is poorly soluble, favour its binding to certain blood proteins. Binding to substances such as albumin and lipoproteins has been shown in vitro (Aoyagi, 1972; Boman, 1972; Nillson, 1972).

Therefore it seems that to prevent reactions to rifampicin the dosage must be adjusted to the patient's ability to metabolize it. Doses smaller than $900 \mathrm{mg}$ should be given to those in whom the blood concentration rises abnormally. With a daily dosage of $600 \mathrm{mg}$ we saw few reactions, and on routine testing of 63 patients 15 days after the end of 12 months' treatment with this dosage we found no antibodies. TABLE V

\section{INTERVALS BETWEEN DOSES}

Patients who have adverse reactions to rifampicin are almost always those who are taking the drug intermittently (usually twice, but sometimes once or thrice weekly) or those who were on a continuous regimen and then resume taking the drug after an interval (cases 7 and 8) (Hasse et al., 1971; Fergusson, 1971). In one patient (case 2 ) the antibody titre notably decreased after a $900-\mathrm{mg}$ dose of rifampicin (table IV) and then rose within 24 hours (Sors et al., 1972). Blajchman et al. (1970) found no active antibody in the presence of platelets after six hours. O'Mahony (1972) found a weaker reaction to the antiglobulin test between two and 18 hours after an oral dose of rifampicin. Thus there is an "unreactive period" when

TABLE III-Titre of Rifampicin Antibodies before and after Adverse Reactions to Rifampicin

\begin{tabular}{|c|c|c|c|c|c|c|c|c|c|c|c|c|c|c|c|c|c|c|c|c|c|c|c|}
\hline \multirow{2}{*}{ Case No. } & \multicolumn{3}{|c|}{ Months before Reactions } & \multicolumn{2}{|c|}{ Reactions } & \multicolumn{18}{|c|}{ Months after Reactions } \\
\hline & 3 & 2 & 1 & No. & Titre & 1 & 2 & 3 & 4 & 5 & 6 & 7 & 8 & 9 & 10 & 11 & 12 & 13 & 14 & 15 & 16 & 17 & 18 \\
\hline $\begin{array}{l}1 \\
2 \\
3 \\
4 \\
5 \\
6 \\
7 \\
8\end{array}$ & 0 & & $\frac{1}{2}$ & $\begin{array}{r}15 \\
5 \\
7 \\
4 \\
1 \\
1 \\
1 \\
1\end{array}$ & $\begin{array}{c}\frac{1}{68} \\
\frac{1}{2} 8 \\
\frac{1}{16} \\
\frac{1}{16} \overline{8} \\
\frac{1}{32}\end{array}$ & $\frac{1}{6}$ & $\frac{1}{\frac{1}{d x}}$ & & $\begin{array}{l}\frac{2}{2} \\
\frac{1}{31}\end{array}$ & & 0 & $\begin{array}{l}\frac{1}{4} \\
0\end{array}$ & & & 0 & & $\begin{array}{l}\frac{1}{2} \\
\frac{1}{2}\end{array}$ & & & $\frac{1}{2}$ & $\begin{array}{l}\frac{1}{2} \\
\frac{1}{2} \\
\frac{1}{2}\end{array}$ & & \\
\hline
\end{tabular}


the antibody titre is low. This has been utilized, with some success, when changing from an intermittent to a daily treatment regimen (Decroix and Pujet, 1971).

Situdies of antibody titres in tolerant patients during the 24 hours after the administration of rifampicin should help to determine the best time to give the next dose. Smalled doses every 12 hours may be found to be advisable in some patients.

\section{IMMUNOLOGICAL TESTS}

Various tests for the presence of antibodies to rifampicin have been used. So far we have found, like Worlledge (1972), the antiglobulin test in the presence of the drug the most dependable (table VI). Positive results will be found, however, whether or not the patient shows any clinical evidence of red cell haemolysis. This has been seen in cases of intolerance to para-aminosalicylic acid (Dausset and Bergerot-Blondel, 1961) and to a contrast medium (Kleinknecht et al., 1974). The antiglobulin test invariably detects the complement but not the immunoglobulin. Probably the antigen-antibody complex is eluted from the red cell surface by the necessary washing. IgM 19S antibodies are identified by chromotography and by precipitation tests (Sors et al., 1972). In a case of thrombocytopenic purpura the antibody was IgG (Blajchman et al., 1970).

TABLE VI-Association between Occurrence of Side Effects (except Liver Damage) and Detection of Rifampicin Antibodies in 123 Cases

\begin{tabular}{|c|c|c|c|c|c|c|c|}
\hline & & & & & \multicolumn{2}{|c|}{ Side Effects } & \multirow{2}{*}{ Total } \\
\hline & & & & & Present & Absent & \\
\hline \multirow[t]{2}{*}{$\begin{array}{l}\text { Antibodies present } \\
\text { Antibodies absent }\end{array}$} & 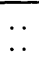 & $\therefore$ & $\therefore$ & $\therefore$ & $\begin{array}{l}7 \\
1\end{array}$ & $\begin{array}{r}0 \\
115\end{array}$ & $\begin{array}{r}7 \\
116\end{array}$ \\
\hline & \multicolumn{4}{|c|}{ Total } & 8 & 115 & 123 \\
\hline
\end{tabular}

In all seven of our intolerant patients with a positive response to the antiglobulin test the antigenic site for the drug was at the junction of the rifampicin nucleus and the side chain (Homberg et al., 1972). There is therefore no cross reaction between rifampicin and rifamycin SV, and a patient intolerant to rifampicin may be given rifamycin SV without fear of side effects and with a resulting decrease in rifampicin antibody titre (Decroix et al., 1973).

\section{MECHANISM OF ADVERSE REACTIONS}

Two different antibodies to rifampicin may exist-one binding to the surface of red cells and the other to platelets (Blajchman et al., 1970). Complement fixation on those cells in vivo may cause intravascular lysis if all fractions of complement are activated or intratissue lysis in various organs, particularly in the Kupffer cells (Cooper and Brown, 1971), if the reaction stops at C3. This accounts for adverse reactions to rifampicin in the form of haemolytic anaemia or thrombocytopenic purpura. In most cases, however, the reaction shows as pyrexia, chills, myalgia, digestive disorders, and sometimes anuria. But it is not known whether these symptoms are associated with the fixation on the red cells of complexes that aotivate the complement and release degradation products or with the fixation of complexes on other cells-for example, mastocytes or vascular endothelial cells. This problem has been discussed (Decroix et al., 1973; Kleinknecht et al., 1972) and is worth investigating further.

We thank Professeur C. Sors (Hôpital de la Salpêtrière, Paris), Dr. A. Auperin (Nevers), and Dr. Pommey (Hôpital St-Denis) for kindly allowing us to include their patients in this study; Mme. Chantal Pujet (Cambo) for performing the rifampicin tests and Mme. Janine Cartron (Centre Départemental de Transfusion Sanguine de Paris) for carrying out the lymphoblastic transformation tests. We are indebted to Mlle. Annie Lecuyer for her excellent technical help in the immunologic tests.

Requests for reprints should be addressed to Professeur G. Decroix, Hôpital Saint-Antoine, 184 Rue de Faubourg SaintAntoine, 75012 Paris.

\section{References}

Aoyagi, T. (1972). Stockholm Workshop on Rifampicin, 2-3 Oct. Aquinas, M., et al. (1972). British Medical fournal, 1, 765.

Blajchman, M. A., Lowry, R. C., Pettit, J. E., and Stradling, P. (1970). British Medical fournal, 3, 24.

Boman, G. (1972). Stockholm Workshop on Rifampicin, 2-3 Oct.

Constans, P., Saintpaul, M., Morin., Y., Bonnaud, G., and Bariety, M. (1968). Revue de Tuberculose et de Pneumologie, 8, 991.

Cooper, A. G., and Brown, D. L. (1971). Clinical and Experimental Immunology, 9,99 .

Dausset, J., and Bergerot-Bloudel, Y. (1961). Vox Sanguinis, 6, 91.

Decroix, G., et al. (1971). Revue de Tuberculose et de Pneumologie, 35, 39. Decroix, G., and Pujet, J. C. (1971). Revue de Tuberculose et de Pneumologie, 35,733 .

Decroix, G., and Pujet, J. C. (1973). Semaine des Hôpitaux, 49, 2219.

Decroix, G., Pujet, J. C., Homberg, J. C., Feldman, A., and Kleinknecht, D. (1973). Nouvelle Presse Médicale, 32, 2093.

Doyle, J. A., et al. (1971). Acta Tuberculosea et Pneumologica Belgica, 62, Eule, $\mathrm{H}$.

(1971). Acta Tuberculosea et Pneumologica Belgica, 62, 325.

Girling

Girling, B., and Fox, W. (1971). British Medical fournal, 4, 213.

Gomi, J. (1971). Acta Tuberculosea et Pneumologica Belgica 64, 313. (1971). Praxis Pneumologie, 25, 466.

Hermann, H. (1972). Stockholm Workshop on Rifampicin, 2-3 Oct.

Homberg, J. C., Pujet, J. C., and Salmon, C. (1972). Stockholm Workshop on Rifampicin, 2-3 Oct.

Kleinknecht, D., Homberg, J. C., and Decroix, G. (1972). Lancet, 1, 1238.

Kleinknecht, D., Deloux, J., and Homberg, J. C. (1974). To be published.

Landsteiner, K." (1945). On the Specificity of Serological Reactions. 2nd edn., p. 156. Oxford, Harvard University Press.

Larbaoui, D., Chaulet, P., and Grosset, J. (1971). Acta Tuberculosea et Pneumologica Belgica, 62, 316.

Mallorquin, C. A., et al. (1971). Acta Tuberculosea et Pneumologica Belgica, 62,318 .

Mannes, P., and Moens, R. (1973). Revue Française des Maladies Respiratoires, 1,130 .

Nillson, B. S. (1972). Stockholm Workshop on Rifampicin, 2-3 Oct.

O'Mahony (Sister Gabriel). (1972). Stockholm Workshop on Rifampicin, $2-3$ Oct.

Poole, G., Stradling, P., and Worlledge, S. (1971). British Medical fournal, 3 ,

Sepulveda, R. et al. (1971). Revista Medica Chile, 99, 934.

Silveira, J., Ferreira, O., Guidice, M., Hiltner, L., and Quiroga, R. A. (1971). Acta Tuberculosea et Pneumologica Belgica, 62, 314

Sors, C., Sarrazin, A., and Homberg, J. C. (1972). Revue de Tuberculose et de Pneumologie, 36, 405.

Verbist, L., Mbete, S., Landuyt, H. Van., Darras, T., and Gyselen, A. (1972). Chest, 61, 555 .

Worlledge, S. (1972). Stockholm Workshop on Rifampicin, 2-3 Oct.

Zierski, M. (1971). Acta Tuberculosea et Pneumologica Belgica, 62, 321. 